\section{DIARY}

British Dental Conference and Exhibition 2012

Date: 26-28 April 2012

Venue: Manchester Central

Convention Complex

www.bda.org/conference

11th Congress of the European

Academy of Paediatric Dentistry

A Crossroads of Knowledge,

Innovation and Expertise

Date: 24-27 May 2012

Venue: Convention Centre,

Strasbourg, France

www.eapd2011.eu

Communicating implants

Date: 23 June 2012

Venue: Novaden Dental Studio, London

Telephone: 02089006040

Email:psochor@me.com

www.courses4implants.com

118th Meeting of the American

Dental Society of Europe

Date: 28-30 June 2012

Location: Vienna, Austria

Telephone: Dr Lloyd Searson,

02076374518

www.ads-eu.org

British Dental Bleaching

Society Conference 2012

Date: 26 July 2012

Venue: Royal College of Surgeons,

London

Telephone: 02072677070

Email: info@bdbs.co.uk

www.bdbs.co.uk

100th FDI Annual

World Dental Congress

Date: 29 August - 1 September 2012

Location: Hong Kong

www.fdicongress.org

17th World Congress

on Dental Traumatology

Science and Art: Overcoming

the Limits of Knowledge

Date: 10-22 September 2012

Venue: Rio de Janeiro, Brazil

www.iadt-dentaltrauma.org

www.sbtd.org.br

Current Concepts in Hard

Tissue Grafting for Accelerated

Implant Reconstruction

Date: 21-22 September 2012

Venue: Spectrumsmiles, Jersey

Telephone: 01534743849

Email:info@spectrumsmiles.co.uk

www.courses 4 implants.com

\section{BRISTOL MARKS BDS CENTENARY}

This November a meeting will be held to mark the centenary of the first graduand to be awarded the Bristol BDS degree. In addition to the Centenary Lecture the occasion will be marked by the launch of the book A history of the University of Bristol Dental School and its site by Chris Stephens.

On 17 November 2012 visitors will be able to tour the school and view the wooden dental chair from 1886 with its 65 inscribed signatures of past Bristol resident dental house surgeons.

Details and booking forms to attend the meeting are available from the Bristol Dental Alumni Association's website (www.bristoldentalalumni. co.uk). A number of graduate years have already arranged reunions to coincide with the meeting and details and guidance notes on organising these can be found on the website.

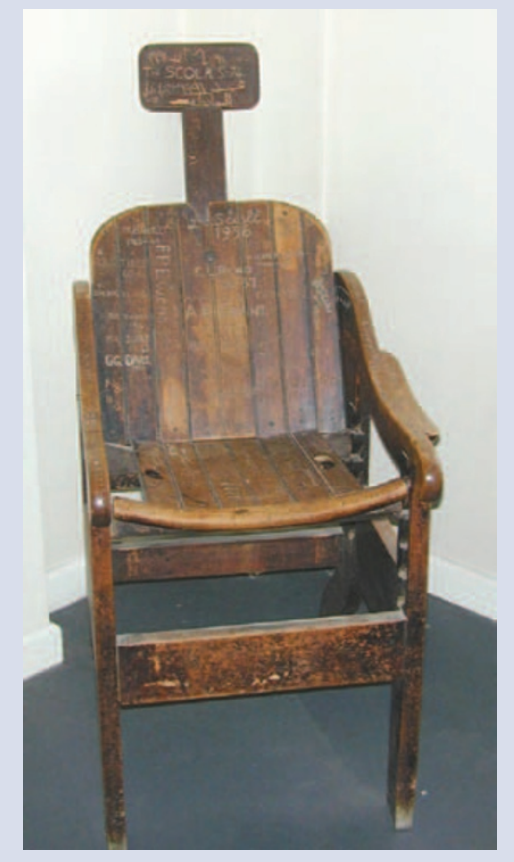

\title{
BDJ IS STILL FIRST CHOICE FOR DENTISTRY
}

The results of the British Dental Trade Association's (BDTA's)

Dental Publication Readership Survey 2011 show that the British Dental Journal $(B D J)$ is the first choice journal for a third (34\%) of respondents, and the most-read publications in terms of Average Issue Readership (AIR) are still the $B D J$ and BDA News.

The $B D J$ and $B D A$ News are among the most regularly-read publications and have the highest proportion of readers reading cover to cover.

The BDTA's results were collated from 228 foursided postal questionnaires mailed to randomly selected dentists on the General Dental Council (GDC) register. $£ 2.50$ was donated to Dentaid for each completed questionnaire and there was a prize draw for $£ 250$ to go to a charity nominated by the winner.

Respondents were $68 \%$ male with an average age of 55 and an average of 33 years' experience. They tend to read dental news or clinical/scientific articles first, depending on the publication. Ninety-eight percent of survey respondents agreed that dental publications provide essential industry information.

\section{EXHIBITION EXPLORES RELATIONSHIP WITH PAIN}

A pop-up exhibition titled Pain at the dentist will be held at a disused dental surgery in Hackney, London, later this month. The Alvarado Gallery exhibition will explore 'our relationship with the endurance of pain'.

The exhibition, which will be held from 20 April to 2 May 2012, will showcase some of the best up and coming artists and illustrators.

The Alvarado Gallery is a new artistic outlet that 'bridges the gap between artists and illustrators and the domestic art collector'. It is set to have a series of themed temporary shows across London, before residing in a yet to be disclosed, fixed residence.

Pain at the dentist is inspired by Ovid's quote 'be patient and be strong; for someday this pain will be useful to you'.

www.alvaradogallery.com

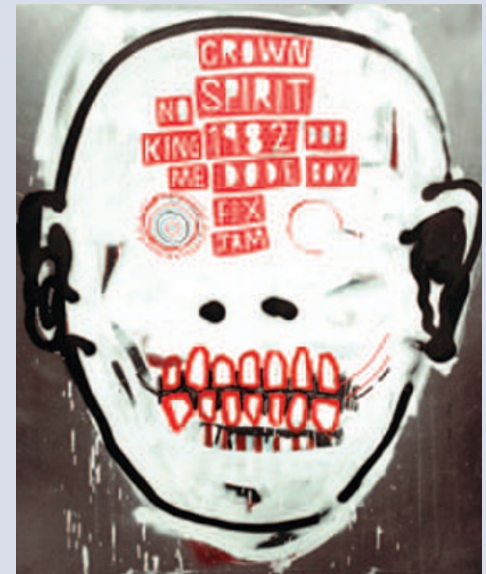

Crown Spirit 1982, 2010, mixed paint on found metal by David Shillinglaw 